\title{
Quality of sleep and use of computers and cell- phones among university students
}

\author{
Diogo von Gaevernitz Lima ${ }^{1}$ \\ DAna Claudia Garabeli Cavalli Kluthcovsky' \\ (D) Luiz Gustavo Rachid Fernandes ${ }^{1}$ \\ (iD) Giovane Okarenski1
}

1. Departamento de Medicina, Universidade Estadual de Ponta Grossa, Ponta Grossa, PR, Brasil.

http://dx.doi.org/10.1590/1806-9282.65.12.1454

\section{SUMMARY}

OBJECTIVE: Evaluate the quality of sleep and its association with the use of computers and cell-phones among medicine and dentistry students.

METHODS: Cross-sectional and comparative study, which evaluated 425 students through a socioeconomic questionnaire, the Pittsburgh Sleep Quality Index(PSQI), and a questionnaire on their use of computers and cell phones.

RESULTS: Poor sleep quality was observed in 61.4\% of medical students and in $60.1 \%$ of dentistry students. Medical students with poor sleep quality had a higher mean time of computer use at night when compared to those with good sleep quality ( $p=0.04)$, as well as for computer $(p<0.001)$ and cell phone use $(p<0.01)$ immediately before bedtime. Dentistry students with poor sleep quality had a higher average time of computer use before bedtime than those with good sleep quality $(p=0.03)$.

CONCLUSION: Students should receive guidance on prevention strategies and quality of sleep care.

KEYWORDS: Sleep. Students, Medical. Students, Dental. Technology.

\section{INTRODUCTION}

The quality of sleep of health students ${ }^{1-4}$ has been studied, and some evidence suggests that their poor sleep quality can be associated with the use of computers at night ${ }^{5}$ and the excessive use of cell phones ${ }^{6}$.

University students are recognized as one of the groups with greater sleep deprivation and one of the most technologically-oriented ${ }^{7}$. The use immediately before bedtime of portable electronic devices that emit light, depending on its intensity, variation, and duration projected on the retina, can lead to the inhibition of the melatonin secretion. These biological effects can perpetuate sleep deficiency and disrupt the circadian rhythm, with consequences on performance, health, and safety ${ }^{8}$.

This is a subject of great importance since the use of technology is present in many aspects of the life of young adults, and its impact is still uncertain. In addition, data from Brazilian literature on the quality of sleep and its association with the use of computers and cell phones by health university students are still limited. This study aimed to evaluate the quality of sleep and its association with the use of computers and cell phones in medical and dentistry students. 


\section{METHODS}

This is a cross-sectional and comparative study, conducted at a university in southern Brasil. A total of 243 medical students and 294 dentistry students were regularly enrolled. A total of 21 medical students and 52 dentistry students did not participate because they were not in the classroom or were not available due to internship activities at the time of collection, as well as in another attempt to include them. We excluded 18 students under the age of 18 years and data of 21 questionnaires that were incomplete. Thus, we analyzed 425 students, 207 of medicine (85.2\%) and 218 of dentistry (74.2\%).

The collection was carried out between March and April 2017, period in which no tests were being carried out. We collected socioeconomic and quality of sleep data using the Pittsburgh Sleep Quality Index (PSQI), translated and validated into Portuguese. Based on the global score, between 0 and 21, students quality of sleep with scores $>5$ were classified as poor and $\leq 5$ as $\operatorname{good}^{9}$. Since we found no instrument in the literature validated on the use of mobile phones and computers, we drew up questions about the use of cell phones and computers, referring to the previous 30 days, on average time of use of computers and cell phones in 24 hours, during the night (between 18h and 6h), and immediately before bedtime.

The association between categorical variables was performed by Pearson's chi-square test and Fisher's exact test. Comparisons regarding the quality of sleep were adjusted for the variables age, gender, and income, when necessary, using logistic regression (enter method ). Continuous variables were compared using the Mann-Whitney test, with their normality checked by histograms and the Shapiro-Wilk test.

We used the Statistical Package for Social Sciences (SPSS15.0) with a significance level of 5\%. The study was approved by the Research Ethics Committee, decision 1,846,977 and CAAE 62388416.3.0000.5215

\section{RESULTS}

Most students of medicine were aged $\geq 21$ years (78.3\%), male (53.6\%), and single (95.2\%). Dentistry students were aged $<21$ years $(54.6 \%)$, female $(73.9 \%)$, and single (98.2\%). Most had a monthly per capita household income $\leq \mathrm{R} \$ 2,000.00$ (57.0\% for medicine and 71.5\% for dentistry). In comparison, dentistry students had a greater proportion of age $<21$ years $(p<0.001)$, females $(p<0.001)$, and lower-income $(p<0.01)$.
Poor sleep quality (PSQI-BR) was found in 61.4\% of the total number of students of medicine and in $60.1 \%$ of dentistry students (Figure 1). Both medical and dentistry students reported, respectively, an average duration of sleep per night of $6.3(+1.1)$ and $6.7(+1.1)$ hours, taking $23.2(+24.9)$ and $23.8(+19.6)$ minutes to fall asleep, and $9.7 \%$ and $8.7 \%$ used medication to help them sleep once or more times per week.

A sleep efficiency greater than $85 \%$ was observed in $78.3 \%$ of medical students and $77.1 \%$ of dentistry students $(\mathrm{p}=0.47)$. Moderate and severe daytime dysfunction was $49.3 \%$ for medical students and $47.2 \%$ for dentistry students $(\mathrm{p}=0.69)$.

FIGURE 1. PREVALENCE OF POOR QUALITY OF SLEEP FOR MEDICINE AND DENTISTRY PROGRAMS, FOR THE TOTAL

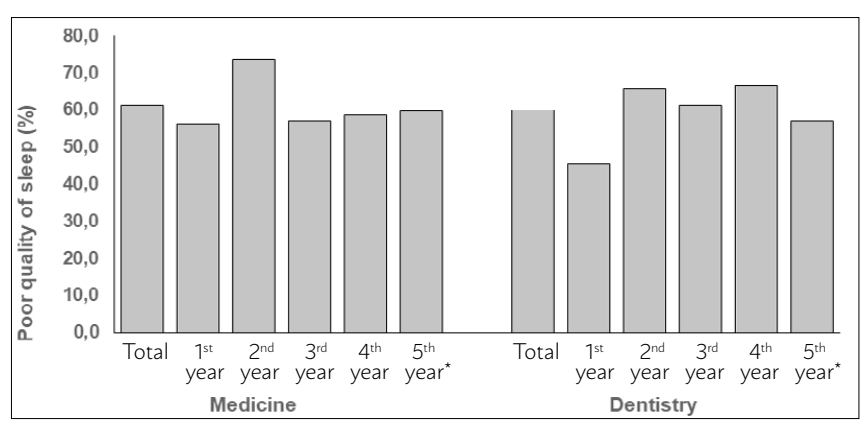

*6th-year students included.

There was no significant difference between good and bad sleep quality between the total number of medicine and dentistry students and between the years of each program. These comparisons were made by logistic regression after adjustments for age, gender, and income, when necessary (Table 1).

For medicine, there was a difference between the mean times of use of computers during the night $(p=0.04)$ and computer $(p<0.001)$ and cell phone use $(p<0.001)$ immediately before sleep, which were greater among students with poor sleep quality. For dentistry, the average time of computer use immediately before sleep $(p=0.03)$ was higher among those with poor sleep quality ( $\mathrm{p}=0.03)$. The power of all these tests was $100 \%$ (Table 2 ).

Considering only students with poor sleep quality, in the comparison between the programs, dentistry students presented greater averages of cell phone use in 24 hours $(p<0.001)$ and during the night $(p<0.001)$, and medicine students had higher averages of computer use in 24 hours ( $\mathrm{p}=0.01)$ and immediately before sleep $(p=0.01)$. None of these variables were associated with socioeconomic factors. 
TABLE 1. COMPARISON BETWEEN MEDICINE AND DENTISTRY STUDENTS REGARDING THE QUALITY OF SLEEP, IN TOTAL AND FOR EACH YEAR OF EACH PROGRAM.

\begin{tabular}{|c|c|c|c|c|}
\hline \multirow{3}{*}{ Variables } & \multicolumn{2}{|c|}{ Quality of sleep } & \multirow{3}{*}{$\mathrm{p}^{*}$} & \multirow{3}{*}{$\mathrm{P}(\mathrm{Cl} 95 \%)^{\star \star}$} \\
\hline & \multirow{2}{*}{\begin{tabular}{|l|} 
Poor \\
$\mathrm{n}(\%)$ \\
\end{tabular}} & \multirow{2}{*}{$\begin{array}{l}\text { Good } \\
n(\%) \\
\end{array}$} & & \\
\hline & & & & \\
\hline All Years & & & 0.79 & $0.89(0.63-1.69)$ \\
\hline Medicine & $127(49.2)$ & $80(47.9)$ & & \\
\hline Dentistry & 131(50.8) & $87(52.1)$ & & \\
\hline First-year & & & 0.35 & $0.86(0.24-3.29)$ \\
\hline Medicine & $22(59.5)$ & $17(48.6)$ & & \\
\hline Dentistry & 15(40.5) & $18(51.4)$ & & \\
\hline Second-year & & & 0.42 & $0.33(0.53-6.49)$ \\
\hline Medicine & $31(51.7)$ & $11(42.3)$ & & \\
\hline Dentistry & $29(48.3)$ & $15(57.7)$ & & \\
\hline Third-year & & & 0.07 & $0.49(0.51-4.05)$ \\
\hline Medicine & $20(36.4)$ & $15(40.5)$ & & \\
\hline Dentistry & $35(63.6)$ & $22(59.5)$ & & \\
\hline Fourth-year & & & 0.49 & $0.89(0.30-2.82)$ \\
\hline Medicine & $17(37.8)$ & $12(46.2)$ & & \\
\hline Dentistry & $28(62.2)$ & $14(53.8)$ & & \\
\hline Fifth-year & & & 0.80 & $0.71(0.42-3.58)$ \\
\hline Medicine\# & $37(60.7)$ & $25(58.1)$ & & \\
\hline Dentistry & $24(39.3)$ & $18(41.9)$ & & \\
\hline
\end{tabular}

${ }^{*}$ Chi-square

** Values after adjustment by logistic regression. All years (age, gender, and income). First-year (age and income). Second-year (age, gender, and income). Third and fourth years (age and gender). Fifth-year (gender and income).

\#6th-year students included.

TABLE 2. COMPARISON OF MEDICINE AND DENTISTRY STUDENTS WITH GOOD AND POOR SLEEP QUALITY REGARDING THE USE OF COMPUTERS AND CELL PHONES.

\begin{tabular}{|c|c|c|c|}
\hline \multirow{2}{*}{ Variables } & Poor Quality of Sleep & Good Quality of Sleep & \multirow{2}{*}{$P^{\star \star}$} \\
\hline & Mean $(\mathrm{SD}){ }^{*}$ Median & Mean $(\mathrm{SD}){ }^{*}$ Median & \\
\hline \multicolumn{4}{|l|}{ Medicine } \\
\hline \multicolumn{4}{|l|}{ Use of the computer } \\
\hline In 24 hours (hours) & $2.6(0.1) 2.0$ & $2.4(0.2) 2.0$ & 0.24 \\
\hline During the night (hours) & $1.9(0.1) 2.0$ & $1.6(0.1) 2.0$ & 0.04 \\
\hline Immediately before sleep (minutes) & $28.0(0.33) 15.0$ & $16.2(3.7) 0.0$ & $<0.001$ \\
\hline \multicolumn{4}{|l|}{ Use of the cell phone } \\
\hline In 24 hours (hours) & $3.9(0.3) 3.0$ & $3.1(0.3) 2.7$ & 0.19 \\
\hline During the night (hours) & $1.8(0.1) 2.0$ & $1.4(0.1) 1.0$ & 0.09 \\
\hline Immediately before sleep (minutes) & $33.3(2.8) 30.0$ & $17.4(2.4) 10.0$ & $<0.001$ \\
\hline \multicolumn{4}{|l|}{ Dentistry } \\
\hline \multicolumn{4}{|l|}{ Use of the computer } \\
\hline In 24 hours (hours) & $2.1(0.1) 2.0$ & $1.9(0.1) 2.0$ & 0.35 \\
\hline During the night (hours) & $1.7(0.1) 2.0$ & $1.5(0.1) 1.2$ & 0.39 \\
\hline Immediately before sleep (minutes) & $21.9(3.1) 0.0$ & $14.4(3.5) 0.0$ & 0.03 \\
\hline \multicolumn{4}{|l|}{ Use of the cell phone } \\
\hline In 24 hours (hours) & $5.3(0.6) 4.0$ & $6.0(0.4) 4.0$ & 0.93 \\
\hline During the night (hours) & $2.5(0.1) 2.0$ & $2.7(0.2) 3.0$ & 0.90 \\
\hline Immediately before sleep (minutes) & $40.5(3.1) 30.0$ & $37.3(3.5) 30.0$ & 0.33 \\
\hline
\end{tabular}

* SD = standard deviation

**Mann-Whitney Test 


\section{DISCUSSION}

Poor quality of sleep was a frequent complaint among medicine and dentistry students, with a prevalence of $61.4 \%$ and $60.1 \%$, respectively. Similar prevalences (PSQI) were found in medical students from other universities, from the 1st to the 6th year in Paraíba $(61.5 \%)^{3}$ and from the 2nd year in Niterói $(64.6 \%)^{2}$. There were higher prevalences among medical students (1st to 4 th year) of Mogi das Cruzes $(84 \%)^{6}$, from the 1 st to the 8 th term in Tubarão $(76.1 \%)^{4}$, in a university of India $(72.9 \%)^{\mathbf{1 0}}$, and in 564 women students of dentistry in an university in Saudi Arabia $(72.5 \%)^{11}$. Whereas in 1st-year medical students of Taiwan, there was a prevalence of $33.8 \%{ }^{12}$.

A study that included medical students found poor sleep quality in only $19.17 \%$ of them in China ${ }^{13}$ and in $14.9 \%$ of the 234 medical students and 42 medical residents of a University in Goiás. Despite the low percentage, the authors concluded that the group researched slept, on average, a lower number of hours, had greater daytime sleepiness, and made greater use of hypnotic drugs in comparison with the general adult population'.

It is important to highlight that the prevalence of poor sleep quality can be related to methodological aspects, such as the collection of data in different periods of the year. For example, there was a significant difference in the prevalence of poor sleep quality (PSQI) between periods pre-test (59\%), post-test (8\%), with no tests $(29 \%)^{14}$. These results increase the concern with students in this study since they presented a high percentage of poor quality of sleep when there were no tests.

In this study, the mean times of computer use during the night and computer and cell phone use immediately before bedtime among students with poor sleep quality were higher than among those with good quality. Among 710 students from different programs of the University of Minas Gerais, the use of the computer between $19 \mathrm{~h}$ and $22 \mathrm{~h}$ or $19 \mathrm{~h}$ and $24 \mathrm{~h}$ was associated with a greater frequency of poor quality of sleep (PSQI), with no difference between the groups regarding watching $t v$ and sleep quality ${ }^{5}$. In a University of Mogi das Cruzes, 76 medical students (1st to 4th year) were evaluated regarding their normal use of cell phones and after not using it one hour before bedtime, for 15 days. After the intervention, there were significant increases in the average sleep duration and reduction in the proportion of poor quality of sleep (PSQI), besides a reduction of daytime sleepiness ${ }^{6}$.
Whereas with 301 medical students from a university of Tubarão, among other findings, the multivariate analysis showed that the greater the time of internet use per day, the greater the chance of poor sleep quality (PSQI), as well as with the use of YouTube 4 .

Similar results were found in other countries. In India, academic females of the 1st year of medicine who used their cell phones for more than 2 hours at night showed a significant correlation between more hours of use and worse quality of sleep (PSQI) ${ }^{15}$. Among 450 students of five universities of medical sciences in Iran, there was a significant correlation between the excessive use of cell phones and the total score of general health and worse quality of sleep (PSQI) ${ }^{16}$. In a study with 350 students of psychology in the United States, there was no correlation between the general use of cell phones and the quality of sleep (Sleep Quality Index). However, the problematic use of cell phones, addictive, problematic, and pathological texting was correlated to a worse quality of sleep ${ }^{7}$. In a university from Turkey, 319 students showed, among other factors, a significant correlation between greater severity of cell phone use (Smartphone Addiction Scale) and global PSQI scores (poorer quality of sleep) ${ }^{\mathbf{1 7}}$.

The use of electronic devices that emit light before bedtime prolongs the time to fall asleep, slows the circadian clock, suppresses melatonin levels, reduces the amount and delays the time of REM sleep, and reduces the state of alert the next morning ${ }^{8}$.

Generally, when using their cell phones or computers, users are very close to the light emitted by the screen and interact actively with the appliances, which differs from the use of passive technology.

From the findings of this study, there is a need to focus on the sleep care of students related to the use of computers and cell phones in the evening and immediately before bedtime. In addition to sleep hygiene measures, psychological interventions should be considered ${ }^{18}$.

The limitations of this study include its cross-sectional nature and the fact that it was carried out in a single institution. Students in the use of psychotropic substances ${ }^{19}$ and/or in treatment for mental health problems may have altered quality of sleep. A greater sample number could find differences in the prevalence of poor sleep quality. Despite these limitations, the results can contribute to a better understanding of the quality of sleep and the use of computers and cell phones in the population studied. 


\section{CONCLUSION}

We observed a high prevalence of poor quality of sleep among students of medicine and dentistry, without difference between them. The mean times of computer use during the night, computer and cell phone use immediately before bedtime (medicine), and the computer immediately before bedtime(dentistry) were higher among students with poor sleep quality were higher than among those with good quality.

\section{Conflicts of interest}

The authors declare there are no conflicts of interest.

\section{Contribution of the authors}

Diogo von Gaevernitz Lima and Ana Claudia Garabeli Cavalli Kluthcovsky: design, methodology, analysis, interpretation of data, drafting of the manuscript, and critical review. Luiz Gustavo Rachid Fernandes and Giovane Okarenski: methodology, data interpretation, manuscript drafting, and critical review.

\section{RESUMO}

OBJETIVO: Avaliar a qualidade de sono e sua associação com uso de computadores e celulares em estudantes de medicina e odontologia.

MÉTODOS: Estudo transversal e comparativo, que avaliou 425 estudantes por meio de questionário socioeconômico, Índice de Qualidade do Sono de Pittsburgh (PSQI) e uso de computador e telefone celular.

RESULTADOS: Sono de má qualidade foi observado em 61,4\% dos estudantes de medicina e em 60,1\% de odontologia. Para os estudantes de medicina, os tempos médios de uso de computador durante a noite $(p=0,04)$ e computador $(p<0,001)$ e celular $(p<0,001)$ imediatamente antes de dormir foram maiores para os estudantes com má qualidade de sono. Para os estudantes de odontologia, o tempo médio de uso do computador imediatamente antes de dormir foi maior para aqueles com má qualidade de sono $(p=0,03)$.

CONCLUSÃo: Os estudantes devem receber orientações sobre estratégias de prevenção e cuidados com a qualidade do sono.

PALAVRAS-CHAVE: Sono. Estudantes de medicina. Estudantes de odontologia. Tecnologia.

\section{REFERENCES}

1. Cardoso HC, Bueno FCC, Mata JC, Alves APR, Jochims I, Vaz Filho IHR, et al. Avaliação da qualidade do sono em estudantes de Medicina. Rev Bras Educ Med. 2009;33(3):349-55.

2. Pagnin D, Queiroz V, Carvalho YT, Dutra AS, Amaral MB, Queiroz TT. The relation between burnout and sleep disorders in medical students. Acad Psychiatry. 2014;38(4):438-44.

3. Rique GL, Fernandes Filho GM, Ferreira AD, Sousa-Muñoz RL. Relationship between chronotype and quality of sleep in medical students at the Federal University of Paraiba, Brazil. Sleep Sci. 2014;7(2):96-102.

4. Marin CE, Feldens VP, Sakae TM. Dependência de internet, qualidade do sono e sonolência em estudantes de Medicina de Universidade do Sul do Brasil. Rev AMRIGS. 2016;60(3):191-7.

5. Mesquita G, Reimão R. Quality of sleep among university students: effects of nighttime computer and television use. Arq Neuropsiquiatr. 2010;68(5):720-5.

6. Freitas CCM, Gozzoli ALDM, Konno JN, Fues VLR. Relação entre uso do telefone celular antes de dormir, qualidade do sono e sonolência diurna. Rev Med. 2017;96(1):14-20.

7. White AG, Buboltz W, lgou F. Mobile phone use and sleep quality and length in college students. Int J Humanit Soc Sci. 2011;1(18):51-8.

8. Chang AM, Aeschbach D, Duffy JF, Czeisler CA. Evening use of light-emitting eReaders negatively affects sleep, circadian timing, and next-morning alertness. Proc Natl Acad Sci U S A. 2015;112(4):1232-7.

9. Bertolazi AN, Fagondes SC, Hoff LS, Dartora EG, Miozzo IC, Barba ME, et al. Validation of the Brazilian Portuguese version of the Pittsburgh Sleep Quality Index. Sleep Med. 2011;12(1):70-5.

10. Shad R, Thawani R, Goel A. Burnout and sleep quality: a cross-sectional questionnaire-based study of medical and non-medical students in India. Cureus. 2015;7(10):e361.
11. Elagra MI, Rayyan MR, Alnemer OA, Alshehri MS, Alsaffar NS, Al-Habib RS, et al. Sleep quality among dental students and its association with academic performance. J Int Soc Prev Community Dent. 2016;6(4):296-301.

12. Kang $\mid \mathrm{H}$, Chen SC. Effects of irregular bedtime schedule on sleep quality, daytime sleepiness, and fatigue among university students in Taiwan. BMC Public Health. 2009;9:248.

13. Feng GS, Chen JW, Yang XZ. Study on the status and quality of sleep-related influencing factors in medical college students. Zhonghua Liu Xing Bing Xue Za Zhi. 2005;26(5):328-31.

14. Ahrberg K, Dresler M, Niedermaier S, Steiger A, Genzel L. The interaction between sleep quality and academic performance. I Psychiatr Res. 2012;46(12):1618-22.

15. Yogesh S, Abha S, Priyanka S. Mobile usage and sleep patterns among medical students. Indian | Physiol Pharmacol. 2014;58(1):100-3.

16. Eyvazlou M, Zarei E, Rahimi A, Abazari M. Association between overuse of mobile phones on quality of sleep and general health among occupational health and safety students. Chronobiol Int. 2016;33(3):293-300.

17. Demirci K, Akgönül M, Akpinar A. Relationship of smartphone use severity with sleep quality, depression, and anxiety in university students. J Behav Addict. 2015;4(2):85-92.

18. Friedrich A, Schlarb AA. Let's talk about sleep: a systematic review of psychological interventions to improve sleep in college students. J Sleep Res. 2018;27(1):4-22.

19. Finger G, Silva ER, Falavigna A. Use of methylphenidate among medical students: a systematic review. Rev Assoc Med Bras. 2013;59(3):285-9. 